\title{
PENGARUH IMPLEMENTASI MOODLE DAN MODEL PEMBELAJARAN KOLABORATIF PADA LINGKUNGAN BLENDED LEARNING TERHADAP PENINGKATAN PEMAHAMAN BELAJAR MAHASISWA
}

\author{
Fadhla Binti Junus**1, Nur Andula ${ }^{2}$ \\ ${ }^{1,2}$ Pendidikan Teknologi Informasi, Fakultas Tarbiyah dan Keguruan, Universitas Islam Negeri Ar-Raniry \\ Email: ${ }^{1}$ fadhlayn@ar-raniry.ac.id, ${ }^{2}$ nurandula2@gmail.com \\ *Penulis Korespondensi
}

(Naskah masuk: 20 Februari 2020, diterima untuk diterbitkan: 29 April 2020)

\begin{abstract}
Abstrak
Lemahnya pemahaman mahasiswa terhadap substansi perkuliahan mengharuskan tenaga pengajar untuk mengulangi pengajaran terkait materi yang belum dipahami tersebut. Hal ini telah mengakibatkan tidak tercapainya capaian pembelajaran yang telah disusun. Kajian ini bertujuan untuk mengukur dampak penggunaan sistem manajemen pembelajaran berbasis Moodle dan model pembelajaran kolaboratif pada blended learning ( $b$ learning) classroom terhadap peningkatan pemahaman mahasiswa. Metode riset yang diaplikasikan yaitu perancangan pra-eksperimental dengan model single group before-and-after design yang melibatkan 104 responden dari mahasiswa Program Studi Pendidikan Teknologi Informasi, Fakultas Tarbiyah dan Keguruan, Universitas Islam Negeri Ar-Raniry yang sedang mengikuti mata kuliah Pengantar E-learning. Adapun instrumen penelitian berupa angket yang disebarkan pada fase sebelum dan sesudah penerapan Moodle dan pembelajaran kolaboratif dilaksanakan. Berdasarkan teknik analisis regresi linier berganda menggunakan piranti lunak SPSS ditemukan bahwa estimasi pengaruh kedua variabel independen sebesar $81,6 \%$ pada tahapan pretest, namun prediksi tersebut bertentangan dengan temuan yang didapat pada fase posttest yang mengindikasikan bahwa persentase implementasi Moodle dan model kolaboratif terhadap pemahaman mahasiswa hanya berpengaruh sebesar 49,9\%. Dengan demikian disimpulkan bahwa hipotesis yang diajukan ditolak dikarenakan tidak terjadi peningkatan pemahaman mahasiswa. Hal ini diperoleh berdasarkan output Model Summary ${ }^{\mathrm{b}}$ dimana nilai kedua koefisien R Square dan Adjusted R Square pada angket posttest lebih kecil nilainya dibandingkan dengan angket pretest.
\end{abstract}

Kata kunci: b-learning, moodle, model pembelajaran kolaboratif, regresi linier berganda, desain praeksperimental, pra uji-purna uji kelompok tunggal

\section{EFFECT OF MOODLE IMPLEMENTATION AND COLLABORATIVE LEARNING MODELS IN BLENDED LEARNING ENVIRONMENT TOWARD IMPROVEMENT OF STUDENTS' LEARNING COMPREHENSION}

Students' lack of understanding toward lecture materials requires extra time in teaching. This has resulted in unfulfilling the designed learning outcomes. This work aims to measure the impact of using the Moodle learning management system (LMS) and collaborative learning model on improving student understanding in blended learning (b-learning) classrooms. The research method used was a pre-experimental design with a single group before-and-after design model involving 104 respondents from the Information Technology Education Study Program at the Ar-Raniry State Islamic University who were attending the E-learning Introductory course. The use of a questionnaire as the research's instrument was distributed in the 'before' and 'after' phases of Moodle implementation and collaborative learning were carried out. According to the results of multiple linear regression analysis using SPSS software, it was found that the influence of the estimated value of the two independent variables was $81.6 \%$ at the pretest stage, but these predictions contradicted the findings obtained at the posttest phase which indicated that the percentage of Moodle implementation and collaborative models was only effect of $49.9 \%$ on students' understanding. In conclusion, thus, the proposed hypothesis was rejected because there was no increment in students' understanding. This was based on the Summary ${ }^{b}$ Model output where the values of both $R$ Square and Adjusted $R$ Square coefficients on the posttest questionnaire were smaller than the pretest questionnaire.

Keywords: b-learning, moodle, collaborative learning model, multiple regression, pre-experimental design, one group pretest-posttest 


\section{PENDAHULUAN}

Pertumbuhan pemanfaatan e-learning sebagai sarana pembelajaran khususnya pada institusi pendidikan tinggi di beberapa negara maju yang muncul pada akhir dekade sembilan puluhan telah memperlihatkan pertumbuhan yang signifikan (Peng, Jiang, \& Zhang, 2013). Hal ini merupakan akibat dari kemajuan teknologi informasi dan komunikasi (TIK) yang tidak mungkin lagi dipisahkan dari sistem pendidikan masa kini (Ramirez, Collazos, \& Moreira, 2018).

Sistem pembelajaran berbasis media TIK yang lebih dikenal dengan istilah e-Learning telah menjadi sistem belajar mengajar formal di banyak institusi pendidikan terkemuka di dunia. Hal ini disebabkan oleh semakin mahalnya biaya penyelenggaraan pendidikan secara tatap muka (face-to-face) yang membutuhkan fasilitas ruangan beserta infrastruktur pendukungnya (Subramanian dkk., 2015).

Mirabolghasemi, Iahad, \& Qomaruddin (2014) juga mengidentifikasi bahwa pemanfaatan e-learning mampu mewujudkan atmosfer pembelajaran yang efisien karena memberikan keleluasaan belajar lebih cepat dan lebih baik bagi peserta didik karena melibatkan berbagai aktivitas kelas yang meliputi materi pembelajaran, tugas, hingga tanya jawab antar pelajar maupun tutorial dengan instruktur dapat dilaksanakan di luar jam pengajaran resmi. Keefektifan pembelajaran dengan melibatkan media e-learning juga diukur dengan meningkatnya pemahaman pembelajar seperti yang telah dibuktikan melalui penelitian terbaru oleh Arifin \& Herman (2018) yang berhasil menerapkan e-learning pada pelajaran matematika di sebuah madrasah ibtidaiyah swasta di Jakarta. Hal senada juga diungkapkan oleh Mas'ud \& Surjono (2018) yang memanfaatkan $e$ learning pada jurusan Teknik Komputer dan Jaringan pada SMKN 3 Kabupaten Pinrang-Sulawesi Selatan untuk meningkatkan capaian keterampilan siswanya.

Keefektifan penggunaan media e-learning dalam proses belajar mengajar (PBM) juga telah terlebih dahulu dikaji pada beberapa perguruan tinggi (PT) di Indonesia, antara lain: (1) Fakultas Ilmu Sosial Universitas Negeri Surabaya (Prasetya, 2013) yang menemukan perbedaan yang menonjol dari hasil belajar mahasiswa yang difasilitasi oleh sistem $e$ learning dibandingkan mereka yang menerapkan PBM secara tradisional, (2) FKIP UNINUS Bandung sebagaimana dipaparkan oleh Karwati (2014) bahwa pemanfaatan e-learning memberikan dampak yang berarti pada mutu belajar, dimana e-learning berkontribusi sebesar 78,5\%, (3) PTIIK Universitas Brawijaya (Pradana, Rachmadi, \& Bachtiar, 2015) yang menggabungkan e-learning dengan model faceto-face, dan (4) Fakultas Ilmu Komputer Universitas Brawijaya yang mengaplikasikan e-learning dalam PBM secara asinkron menyatakan bahwa terjadi peningkatan kualitas proyek pada matakuliah Manajemen Proyek Sistem Informasi (Herlambang \& Hidayat, 2016).
Meskipun kajian tersebut di atas membuktikan keunggulan PBM bermedia e-learning, Mungania ( dalam Bonk dkk., 2007) memaparkan tujuh kekurangan sistem e-learning yang menjadi hambatan dalam pelaksanaannya. Hambatan tersebut meliputi hambatan personal, gaya belajar, instruksional, organisasi, situasi, stabilitas isi materi, dan masalah teknologi. Selain itu, Bowers, Justice, \& Valley (2015) mengemukakan bahwa terdapat angka drop out yang tinggi pada peserta PBM yang mengikuti kelas berbasis e-learning dikarenakan kurangnya interaksi sosial dengan pengajar.

Untuk mengatasi permasalahan tersebut maka dapat diterapkan kolaborasi PBM tradisional dengan teknologi e-learning, bila tidak terdapat jarak antara pengajar dan pembelajar (Comerchero, 2006). Penggabungan sistem e-learning ke dalam sistem pembelajaran tradisional dianggap lebih menguntungkan karena aktivitas penyampaian materi dan evaluasi menjadi lebih fleksibel (Songkram dkk., 2015).

Kombinasi kedua sistem tersebut lebih dikenal dengan istilah blended learning (b-learning) yang didefinisikan sebagai pendistribusian lingkungan belajar asinkronus dengan lebih menekankan pada pola pembelajaran berorientasi student centric yang tetap dikontrol langsung oleh pengajar (Graham, 2006). Alasan penggunaan sistem b-learning seperti yang diidentifikasi oleh Osguthorpe \& Graham (2003) bertujuan untuk (1) memperkaya metode pengajaran, (2) memberi akses ke ilmu pengetahuan, (3) interaksi sosial, (4) menyediakan ruang belajar individu, (5) menghemat biaya, dan (6) memudahkan pembaruan materi.

Merujuk kepada hasil penelitian oleh Medina (2018) - yang mengkaji manfaat yang didapatkan dari PBM menggunakan sistem b-learning pada $18 \mathrm{PT}$ terkemuka di benua Eropa, Amerika, Australia, dan Asia - terungkapkan bahwa sistem b-learning berperan sebagai pendukung literasi digital bagi mahasiswa yang mampu menghasilkan sebuah komunitas pembelajaran dan memberikan kesempatan kolaborasi antara mahasiswa dan staf pengajar. Di samping itu, b-learning tidak hanya menawarkan keuntungan dari sisi manajemen dan pengalaman pembelajaran personal, namun juga menghemat biaya dan waktu.

Selain di PT, sistem b-learning juga telah diterapkan untuk mengembangkan keterampilan pekerja seperti yang dilakukan oleh IBM, Sun Microsystem, Oracle, Avaya, dan Microsoft (Graham, 2004). Perusahaan- perusahaan terkemuka tersebut mengaplikasikan b-learning untuk memberikan pelatihan kerja sebagai bentuk dukungan dalam mengembangkan karir para karyawannya.

Kedua penelitian di atas membuktikan bahwa sistem $b$-learning tidak hanya bermanfaat bagi dunia pendidikan namun juga dunia industri. Para akademisi menggunakan sistem belajar online untuk 
membagikan sumber daya pembelajaran, sehingga ketika mengajar di kelas dapat lebih fokus pada pengembangan keterampilan mahasiswa dengan mengaplikasikan kemampuan berpikir logis untuk menemukan solusi terhadap studi kasus yang diberikan. Adapun metode tatap muka pada sistem $b$ learning di industri difokuskan pada pembelajaran aktif dan pengalaman mengaplikasikan pengetahuan, sedangkan platform e-learning digunakan untuk proses transfer pengetahuan dalam lingkungan kerja yang dapat disesuaikan dengan kecepatan belajar setiap karyawan.

Menurut Kovacova \& Vackova (2015) pemanfaatan media e-learning oleh sistem b-learning pada PT merupakan cara yang efisien untuk berbagi materi pembelajaran dari dosen ke mahasiswa sehingga mahasiswa dapat belajar secara mandiri dengan lebih cepat sebelum PBM di kelas dimulai. Meskipun hal tersebut menawarkan fleksibilitas dalam mengakses bermacam sumber belajar, namun merancang materi pembelajaran yang digunakan dalam lingkungan belajar campuran merupakan hal yang sulit dan memakan waktu dikarenakan memerlukan kerjasama dengan berbagai pihak seperti teknisi, perancang grafis, dan programmer. Selain itu, perancangan materi pembelajaran harus memikirkan juga bagaimana cara penyajian yang tepat agar dapat digunakan untuk mendukung personalisasi pembelajaran yang mudah dipahami sesuai kebutuhan mahasiswa yang beragam (Boelens, Voet, \& Wever, 2018; Medina, 2018).

Kelemahan lainnya dari model b-learning juga diungkapkan oleh Graham \& Dziuban (2006), jika fokus PBM lebih menekankan pada metode pengajaran daripada pengalaman pembelajaran maka metode b-learning menjadi tidak informatif. Di samping itu, Multilateral Grundtvig Project (2013) menelaah isu subyektifitas seperti latar belakang siswa, kurikulum, desain pembelajaran, manajemen institusi dan teknologi menjadi salah satu isu kelemahan kualitas b-learning. Untuk mengatasi kelemahan tersebut, pelaksanaan b-learning di Indonesia sendiri ditetapkan melalui Peraturan Menteri Pendidikan dan Kebudayaan Nomor 49 (2014) perihal Standar Nasional Pendidikan Tinggi pasal 14 ayat (2) yang menuturkan bahwa " proses pembelajaran melalui kegiatan kurikuler wajib menggunakan metode pembelajaran yang efektif". Mengutip Herlambang \& Hidayat (2016) yang dimaksud efektif pada kebijakan tersebut adalah mekanisme pembelajaran harus dilaksanakan dalam suasana yang ideal dan bersifat kolaboratif.

Roberts (2005) mendefinisikan pembelajaran kolaboratif sebagai sebuah bentuk asistensi yang diberikan oleh guru dan siswa yang memiliki tingkat pemahaman lebih tinggi kepada siswa yang kurang memahami. Secara akademis, teknik kolaboratif ditengarai mampu mengembangkan kemampuan berpikir kritis dimana siswa dapat terstimulasi dalam menyampaikan ide dan pemikirannya. Di samping itu, dengan terlibatnya siswa secara aktif dalam memecahkan persoalan dalam proses pembelajaran akan mampu menaikkan kualitas hasil belajar kelas tersebut.

Menurut Deejring (2014) teknik pembelajaran kolaboratif membantu siswa dalam bertukar pengetahuan dari berbagai perspektif sehingga mampu mencegah kesalahpahaman terhadap suatu permasalahan melalui pemanfaatan multimedia dan teknologi terkini. Ia juga memaparkan salah satu sumber daya teknologi dalam teknik pembelajaran kolaboratif adalah dengan melibatkan pembelajaran berbasis web karena piranti tersebut menyediakan ruang berbagi pengalaman dan pengetahuan serta membangun kerjasama antar siswa tanpa dibatasi jarak dan waktu.

Maraknya penggunaan internet dan masifnya perkembangan Web 2.0 mengakibatkan banyak bermunculan piranti lunak yang mendukung pembelajaran kolaboratif. Hal ini memicu para peserta didik yang memiliki kesamaan minat untuk bertukar informasi dan berbagi pengetahuan melalui forum diskusi dalam jaringan internet. Bahkan sejumlah lembaga pendidikan telah memulai mempersiapkan para siswanya untuk membiasakan diri berkolaborasi dalam berbagai tugas dengan memanfaatkan alat bantu yang tersedia melalui internet (Cheung \& Vogel, 2013). Meskipun begitu, keberhasilan kelas kolaboratif tidak ditentukan semata-mata oleh penggunaan teknologi pembelajaran karena menurut temuan Cheung \& Vogel (2013) kemampuan berbagi informasi merupakan kunci utama keberhasilan metode pembelajaran kolaboratif. Hal senada juga telah lebih dahulu dipaparkan dalam riset oleh Dillenbourg \& Fischer (2007) yang mengemukakan bahwa sejak dimulainya penelitian di bidang computer-supported collaborative learning (CSCL) di era 80-an, mayoritas peneliti menyimpulkan keberhasilan model kolaboratif terletak pada produktivitas para kolaboratornya, yakni pengajar, pembelajar, dan teknologi yang memfasilitasinya.

Artikel ini memaparkan hasil kajian pada penerapan strategi pembelajaran blended learning melalui pendekatan collaborative learning model untuk meningkatkan kemampuan pemahaman mahasiswa terhadap matakuliah Pengantar ELearning yang sedang dipelajari di Program Studi Pendidikan Teknologi Informasi (PTI), Fakultas Tarbiyah dan Keguruan (FTK), Universitas Islam Negeri (UIN) Ar-Raniry Banda Aceh. Hal ini dilakukan untuk mengatasi permasalahan utama dalam PBM yang dihadapi oleh dosen, dimana lemahnya pemahaman mahasiswa terhadap suatu materi mengharuskan tenaga pengajar untuk mengulangi penjelasan terkait perkuliahan sehingga diperlukan jadwal tambahan yang mengakibatkan tidak tercapainya capaian pembelajaran yang telah disusun oleh program studi. Demi mengatasi kendala tersebut maka diuji cobakan metode pembelajaran 
kolaboratif yang dipadukan dengan platform elearning Moodle guna menilai seberapa besar efek keduanya terhadap peningkatan pemahaman pembelajaran mahasiswa.

\section{METODE PENELITIAN}

Metode kajian ini merupakan penelitian kuantitatif yang menggunakan model perancangan pra-eksperimental karena hasil ekperimennya masih dipengaruhi oleh faktor lain di luar kajian (Sugiyono, 2015). Salah satu model yang paling penting dan sering diaplikasikan yaitu model single group pretestposttest design atau dikenal juga sebagai before-andafter design, dimana istilah before merujuk pada pengukuran yang dilakukan sebelum suatu perlakuan diberikan kepada sebuah kelompok, sedangkan after merupakan kondisi pengukuran setelah intervensi tertentu diberikan kepada kelompok yang sama (Robson dkk., 2001). Model ini biasa digunakan untuk mengevaluasi kebijakan pendidikan dengan melakukan sejumlah praktik intervensi dan mengukur keefektifannya (Spurlock, 2018; Marsden \& Torgerson, 2012).

Menurut Robson dkk. (2001) hasil pengukuran dari model pretest-posttest ini lebih efektif untuk mendemonstrasikan dampak yang ditimbulkan langsung pada jangka waktu yang pendek. Pengaruh yang tampak diukur dengan cara membandingkan kondisi sebelum dan setelah perlakuan diberikan. Bila terdapat peningkatan persentase terhadap kondisi setelah perlakuan maka pengujian yang dilakukan dapat dianggap efektif. Namun sebaliknya, bila persentase sebelum intervensi dilakukan lebih tinggi maka pengujian tersebut dinilai tidak efektif.

Riset ini dilakukan selama satu semester terhadap 104 sampel mahasiswa (57\% pria dan $43 \%$ wanita) yang mengikuti mata kuliah Pengantar ELearning pada Program Studi PTI, FTK-UIN ArRaniry Banda Aceh dalam tahun ajaran 2018/2019. Jumlah sampel (n) diambil dari populasi (N) yang berjumlah 140 orang dengan tingkat akurasi (d) 95\% melalui persamaan (1) menggunakan rumus Slovin (Sugiyono 2015).

$\mathrm{n}=\frac{N}{N(d)^{2}+1}$

Sehingga perhitungan banyaknya sampel adalah $\mathrm{n}=$ $140 /\left(140 *(0,1)^{2}+1\right)=103,703$ yang dibulatkan menjadi 104 sampel.

Kajian ini menggunakan instrumen utama berupa kuesioner yang terdiri dari 23 butir pertanyaan bertipe data skalar yang dikembangkan berdasarkan kajian yang dilakukan oleh Dillenbourg \& Fischer (2007), Cheung \& Vogel (2013), dan Karwati (2014). Sedangkan pengukuran bobot untuk setiap butir menggunakan skala Likert yang disajikan menggunakan Rating Scale. Konstruksi angket dan operasional variabel penelitian dirincikan dalam Tabel 1 berikut.

Tabel 1. Konstruksi Angket dan Operasional Variabel Penelitian

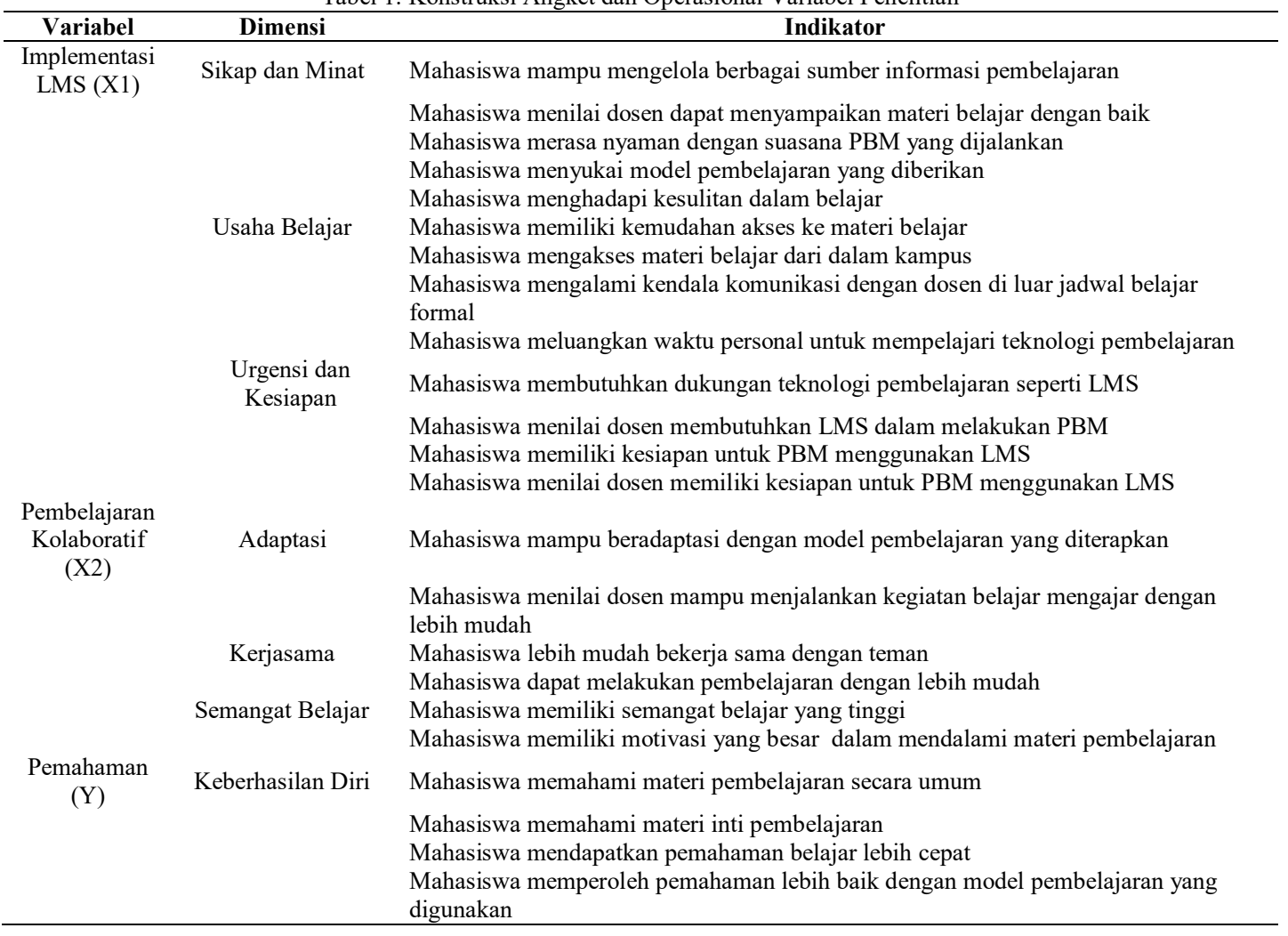


Penyebaran angket dilakukan sebanyak dua kali, pertama sebelum pembelajaran diintervensi dengan LMS dan model pembelajaran kolaboratif (pretest) dan kedua setelah perlakuan diberikan (posttest). Soalan yang diajukan mewakili dua buah variabel mandiri (X) dan sebuah unsur terikat (Y), dimana unsur bebasnya terdiri dari dua buah variabel (X1, X2) dimana X1 merepresentasikan implementasi LMS dan X2 mewakili model pembelajaran kolaboratif, sedangkan variabel $\mathrm{Y}$ digambarkan sebagai peningkatan pemahaman belajar mahasiswa. Sehingga pengajuan hipotesa pada penelitian ini adalah untuk membuktikan implementasi LMS pada kelas blended learning (X1) melalui pendekatan model pembelajaran kolaboratif (X2) berpengaruh terhadap peningkatan pemahaman belajar mahasiswa (Y).

Data yang diperoleh dari kedua fase kemudian ditabulasikan dengan menjumlahkan skor dari setiap butir pertanyaan dan dilanjutkan dengan pemetaan operasional variabel terhadap soalan-soalan yang diberikan. Selanjutnya, guna memperoleh gambaran pengaruh dari seluruh variabel tersebut diaplikasikan teknik analisa dengan metode Regresi Linier Berganda menggunakan perangkat lunak SPSS 25.

Analisis regresi linier berganda atau dikenal juga dengan multiple regression mengukur suatu relasi fungsional antara satu peubah terikat dengan lebih dari satu peubah otonom (Nazir, 2017). Merujuk pada penjelasan Abdillah (2018) teknik regresi dilakukan melalui serangkaian langkah yang terdiri dari komputasi variabel serta uji asumsi klasik yang dilakukan secara simultan dengan uji kelayakan model regresi untuk kedua fase pretest dan posttest.

\section{HASIL DAN PEMBAHASAN}

Sebelum menjalankan teknik analisis regresi linier berganda dilakukan pengujian statistika deskriptif terlebih dahulu. Hal ini bertujuan untuk mengetahui rata-rata nilai jawaban responden dan memastikan bahwa tidak terdapat missing value dari respon yang diperoleh. Gambar 1 dan Gambar 2 menyajikan output statistika deskriptif yang menjelaskan distribusi frekuensi dan nilai rata-rata seluruh variabel yang diuji pada fase pretest dan posttest.

\begin{tabular}{ll|r|r} 
& Mean & Std. Deviation & \multicolumn{1}{l}{ N } \\
\hline PEMAHAMAN & 2.1659 & .90950 & 104 \\
\hline Implementasi EL & 2.2212 & .93898 & 104 \\
\hline Collaborative Learning & 2.2340 & .99120 & 104 \\
\hline
\end{tabular}

Gambar 1. Statistika Deskriptif Angket Pretest

\begin{tabular}{lc|r|r} 
& Mean & Std. Deviation & \multicolumn{1}{l}{ N } \\
\hline PEMAHAMAN & 14,0769 & 2,78934 & 104 \\
\hline Implementasi EL & 45,8173 & 7,84778 & 104 \\
\hline Collaborative Learning & 19,8942 & 3,87904 & 104 \\
\hline
\end{tabular}

Gambar 2. Statistika Deskriptif Angket Posttest
Analisis regresi berganda diawali dengan melakukan komputasi variabel yang terdiri dari uji asas (validity) dan keterandalan (reliability). Uji asas bermaksud untuk menilik korelasi antara setiap butir pertanyaan dengan total konstruk variabel. Menurut Sugiyono (2015) uji validitas dilakukan dengan membandingkan angka $\mathrm{R}$ hitung dengan $\mathrm{R}$ tabel, dimana nilai minimal $\mathrm{R}$ tabel adalah 0,3 .

Tabel 2 dan Tabel 3 merupakan ringkasan nilai $\mathrm{R}$ hitung angket Pretest dan Postest yang diperoleh dari output korelasi Pearson antar variabel. Dimana 13 butir pertanyaan merupakan konstruk bagi variabel X1 (Implementasi LMS), 6 pertanyaan bagi variabel X2 (Collaborative Learning), dan 4 soalan berkaitan dengan variabel Y (Pemahaman).

\begin{tabular}{cccc} 
Tabel 2. Ringkasan Output Korelasi Pearson Angket Pretest \\
\hline Item & $\begin{array}{c}\text { Implementasi } \\
\text { LMS }\end{array}$ & $\begin{array}{c}\text { Collaborative } \\
\text { Learning }\end{array}$ & Pemahaman \\
\hline Q1 & .620 & - & - \\
Q2 & .756 & - & - \\
Q3 & .711 & - & - \\
Q7 & .851 & - & - \\
Q8 & .795 & - & - \\
Q9 & .801 & - & - \\
Q10 & .671 & - & - \\
Q11 & .762 & - & - \\
Q15 & .737 & - & - \\
Q18 & .821 & - & - \\
Q19 & .819 & - & - \\
Q21 & .757 & - & - \\
Q22 & .764 & - & - \\
Q12 & - & .909 & - \\
Q13 & - & .828 & - \\
Q14 & - & .905 & - \\
Q16 & - & .894 & - \\
Q17 & - & .722 & - \\
Q20 & - & .885 & .833 \\
Q4 & - & - & .872 \\
Q5 & - & - & .878 \\
Q6 & - & - & \\
Q23 & - & - & - \\
\hline & & - & - \\
\hline
\end{tabular}

Berdasarkan Tabel 2 dapat dilihat bahwa angka $\mathrm{R}$ hitung untuk 23 butir pertanyaan dalam angket pretest antar ketiga variabel bernilai lebih besar dari 0,3 . Hal serupa juga terjadi pada uji validitas angket posttest, sebagaimana tampak pada Tabel 3, dimana besaran seluruh $\mathrm{R}$ hitungnya menunjukkan nilai di atas batas minimal $R$ tabel. Dengan demikian hasil uji validitas variabel terhadap total konstruk variabel untuk kedua jenis angket penelitian dinyatakan valid.

Selanjutnya dilakukan uji reliabilitas yang bertujuan untuk menilai keabsahan instrumen penelitian dengan melihat perolehan dari bobot Cronbach Alpha. Kuesioner yang digunakan dinyatakan reliabel bila angka Cronbach Alpha lebih besar dari 0,60 (Ghozali, 2016; Abdillah, 2018).

Adapun hasil uji reliabilitas variabel pada angket pretest, seperti yang diperlihatkan pada Gambar 3, menunjukkan nilai Cronbach Alpha ketiga variabel berturut-turut adalah 0,937, 0,928, dan 0,821 untuk variabel X1, X2 dan Y. 


\begin{tabular}{cccc}
\multicolumn{5}{c}{ Tabel 3. Ringkasan Output Korelasi Pearson Angket } \\
\hline \multicolumn{4}{c}{ Posttest } \\
\hline Item & $\begin{array}{c}\text { Implementasi } \\
\text { LMS }\end{array}$ & $\begin{array}{c}\text { Collaborative } \\
\text { Learning }\end{array}$ & Pemahaman \\
\hline Q1 & .601 & - & - \\
Q2 & .583 & - & - \\
Q3 & .639 & - & - \\
Q7 & .609 & - & - \\
Q8 & .748 & - & - \\
Q9 & .670 & - & - \\
Q10 & .556 & - & - \\
Q11 & .608 & - & - \\
Q15 & .382 & - & - \\
Q18 & .668 & - & - \\
Q19 & .699 & - & - \\
Q21 & .702 & - & - \\
Q22 & .599 & - & - \\
Q12 & - & .838 & - \\
Q13 & - & .692 & - \\
Q14 & - & .790 & - \\
Q16 & - & .800 & - \\
Q17 & - & .475 & - \\
Q20 & - & .636 & - \\
Q4 & - & - & .802 \\
Q5 & - & - & .773 \\
Q6 & - & - & .698 \\
Q23 & - & - & .583 \\
& & &
\end{tabular}

\begin{tabular}{|c|c|c|c|c|c|}
\hline \multicolumn{2}{|c|}{ Reliability Statistics } & \multicolumn{2}{|c|}{ Reliability Statistics } & \multicolumn{2}{|c|}{ Reliability Statistics } \\
\hline $\begin{array}{l}\text { Cronbach's } \\
\text { Alpha }\end{array}$ & $\mathrm{N}$ of ltems & $\begin{array}{l}\text { Cronbach's } \\
\text { Alpha }\end{array}$ & $\mathrm{N}$ of ltems & $\begin{array}{l}\text { Cronbach's } \\
\text { Alpha }\end{array}$ & $\mathrm{N}$ of ltems \\
\hline .937 & 13 & .928 & 6 & .821 & 4 \\
\hline
\end{tabular}

Gambar 3. Reliabilitas Variabel X1, X2, dan Y Angket Pretest

Sedangkan hasil uji reliabilitas untuk angket posttest sebagaimana disajikan oleh Gambar 4 memperlihatkan angka $0,858,0,776$, dan 0,668 untuk ketiga variabel $\mathrm{X} 1, \mathrm{X} 2$ serta $\mathrm{Y}$.

\begin{tabular}{|c|c|c|c|c|c|}
\hline \multicolumn{2}{|c|}{ Reliability Statistics } & \multicolumn{2}{|c|}{ Reliability Statistics } & \multicolumn{2}{|c|}{ Reliability Statistics } \\
\hline $\begin{array}{c}\text { Cronbach's } \\
\text { Alpha }\end{array}$ & N of items & $\begin{array}{l}\text { Cronbach's } \\
\text { Alpha }\end{array}$ & $\mathrm{N}$ of items & $\begin{array}{c}\text { Cronbach's } \\
\text { Alpha }\end{array}$ & $\mathrm{N}$ of ltems \\
\hline ,858 & 13 & .776 & 6 & 668 & 4 \\
\hline
\end{tabular}

$\overline{\text { Gambar 4. Reliabilitas }} \overline{\text { Variabel X1, X2, dan }} \overline{\text { Y Angket Posttest }}$

Dikarenakan seluruh skor Cronbach Alpha lebih dari 0,60 dengan demikian seluruh variabel dalam instrumen pretest dan posttest dinyatakan telah memenuhi nilai keabsahan.

Setelah hasil komputasi dinyatakan valid dan absah, selanjutnya dilakukan uji asumsi klasik yang bertujuan untuk mengestimasi model regresi linier. Pada SPSS, pengujian ini dilakukan secara simultan dengan uji kelayakan model regresi.

Asumsi klasik yang diujikan pada penelitian ini adalah multikolinieritas. Model ini bertujuan untuk mengetahui apakah keterhubungan antar variabel telah linier dengan merujuk pada kadar Tolerance dan Variance Inflating Factor (VIF) yang terdapat pada output Coefficients ${ }^{\mathrm{a}}$ sebagaimana diperlihatkan oleh Gambar 5 dan Gambar 6.

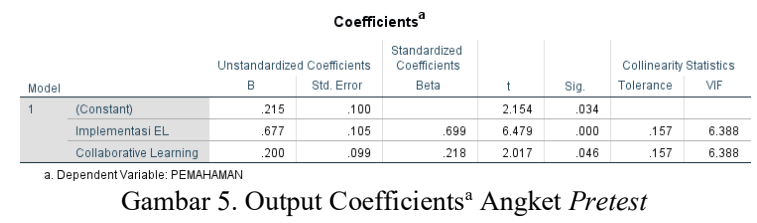

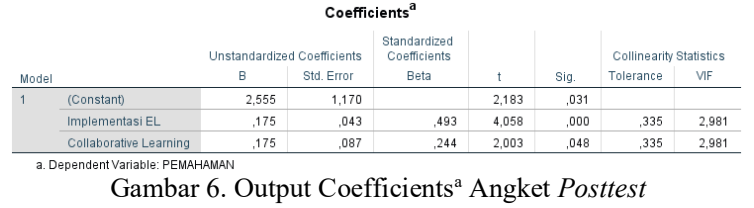

Merujuk pada teori yang dipaparkan Abdillah (2018) kedua nilai Tolerance dan VIF berguna pada pengujian yang mempunyai variabel lepas lebih dari satu. Sebuah paradigma regresi terbebas dari gejala multikolinieritas apabila bobot parameter Tolerance bernilai lebih dari 0,1 dan parameter VIF kurang dari 10 (Ghozali, 2016). Menurut Gambar 5 dan Gambar 6 tersebut maka model regresi yang akan diestimasi terbebas dari multikolinieritas karena nilai parameter Tolerance untuk kedua angket adalah 0,157 dan 0,335 . Begitu pula untuk parameter VIF keduanya dimana bernilai 6,388 pada angket pretest dan 2,981 pada posttest.

Dikarenakan telah lolos pengujian asumsi klasik maka proses seterusnya dilanjutkan dengan pengujian kelayakan model regresi guna membuktikan hipotesis yang diajukan. Terdapat tiga pengujian yang dilaksanakan pada tahapan terakhir ini yang mencakup uji coba T, F, dan koefisien determinan.

Uji coba $\mathrm{T}$ bertujuan untuk mengestimasi ketepatan parameter pada model regresi. Di samping itu, analisis nilai $\mathrm{T}$ juga berfungsi mengukur signifikansi dampak variabel otonom pada variabel terkait. Ketepatan hasil uji diamati dari angka pada kolom Sig. pada output Coefficients ${ }^{\mathrm{a}}$, dimana bila nilai signifikansinya lebih kecil atau sama dengan tingkat error 0,05 , maka dapat diinterpretasikan bahwa variabel otonom sangat berpengaruh pada faktor terikatnya (Abdillah, 2018).

Sebagaimana yang tampak pada Gambar 5 dan juga Gambar 6 dapat dikonklusikan bahwa variabel $\mathrm{X} 1$ (implementasi EL) dan X2 (collaborative learning) berpengaruh signifikan terhadap variabel $\mathrm{Y}$ (pemahaman). Hal ini berdasarkan hasil uji $\mathrm{T}$ dari kedua angket menghasilkan kadar signifikansi di bawah 0,05 , dimana besaran signifikansi X1 $=0,000$ untuk kedua angket dan X2 $=0,46$ bagi angket pretest serta 0,48 bagi posttest.

Selanjutnya dilakukan Uji F untuk menilai kelayakan model regresi yang akan diestimasi. Merujuk pada Abdillah (2018) tabel analysis of varian (ANOVA) digunakan untuk menginterpretasi parameter $\mathrm{F}$ ratio. Parameter ini berfungsi sebagai pengukur secara keseluruhan apakah spesifikasi model sudah tepat sehingga bila hasilnya tidak signifikan (nilai F lebih besar dari 0,05) maka model estimasian regresi tidak valid. Hal ini berakibat pada tidak dapat dilakukannya interpretasi lanjutan.

Hasil Uji F berdasarkan output ANOVA $^{a}$ sebagaimana ditampilkan oleh Gambar 7 dan Gambar 8 menunjukkan bahwa pengujian model regresi pada tahap pretest dan posttest dikatakan layak dan tepat karena nilai signifikansinya $(0,000)$ kurang dari tingkat kesalahan 0,05. Dengan demikian dapat 
dikonklusikan bahwa pola regresi ini patut digunakan dalam mendeskripsikan pengaruh unsur bebas terhadap faktor terikatnya.

\begin{tabular}{|c|c|c|c|c|c|c|}
\hline \multicolumn{7}{|c|}{ ANOVA $^{\mathrm{a}}$} \\
\hline \multicolumn{2}{|l|}{ Model } & $\begin{array}{l}\text { Sum of } \\
\text { Squares }\end{array}$ & df & Mean Square & $\mathrm{F}$ & Sig. \\
\hline \multirow[t]{3}{*}{1} & Regression & 69.510 & 2 & 34.755 & 223.713 & $.000^{\mathrm{b}}$ \\
\hline & Residual & 15.691 & 101 & .155 & & \\
\hline & Total & 85.201 & 103 & & & \\
\hline
\end{tabular}

\begin{tabular}{|c|c|c|c|c|c|c|}
\hline \multicolumn{7}{|c|}{ ANOVA $^{\mathrm{a}}$} \\
\hline \multicolumn{2}{|c|}{ Model } & $\begin{array}{l}\text { Sum of } \\
\text { Squares }\end{array}$ & $d f$ & Mean Square & $\mathrm{F}$ & Sig. \\
\hline \multirow[t]{3}{*}{1} & Regression & 399,820 & 2 & 199,910 & 50,281 & $.000^{\mathrm{b}}$ \\
\hline & Residual & 401,564 & 101 & 3,976 & & \\
\hline & Total & 801,385 & 103 & & & \\
\hline
\end{tabular}

Langkah terakhir dari analisis regresi pada penelitian ini adalah pengujian koefisien determinan. Pengujian ini bertujuan untuk menjelaskan variasi pengaruh unsur bebas terhadap faktor terikatnya. Intepretasi hasil akhir dilihat dari output Model Summary ${ }^{\mathrm{b}}$ seperti yang ditampakkan oleh Gambar 9 serta Gambar 10.

\begin{tabular}{|c|c|c|c|c|}
\hline \multicolumn{5}{|c|}{ Model Summary } \\
\hline Model & $\mathrm{R}$ & R Square & $\begin{array}{c}\text { Adjusted R } \\
\text { Square }\end{array}$ & $\begin{array}{l}\text { Std. Error of } \\
\text { the Estimate }\end{array}$ \\
\hline 1 & $.903^{\mathrm{a}}$ & .816 & .812 & .39415 \\
\hline \multicolumn{5}{|c|}{$\begin{array}{l}\text { a. Predictors: (Constant), Collaborative Learning, } \\
\text { Implementasi EL }\end{array}$} \\
\hline \multicolumn{5}{|c|}{ b. Dependent Variable: PEMAHAMAN } \\
\hline
\end{tabular}

\begin{tabular}{|c|c|c|c|c|}
\hline \multirow[b]{2}{*}{ Model } & \multicolumn{4}{|c|}{ Model Summary } \\
\hline & $\mathrm{R}$ & R Square & $\begin{array}{l}\text { Adjusted R } \\
\text { Square }\end{array}$ & $\begin{array}{l}\text { Std. Error of } \\
\text { the Estimate }\end{array}$ \\
\hline 1 &, $706^{a}$ & 499 & ,489 & 1,99396 \\
\hline
\end{tabular}

Nilai koefisien dilihat dari perbandingan $R$ Square dengan Adjusted R Square. Jika Adjusted R Square lebih besar dari R Square maka penambahan variabel independen menghasilkan variansi pengaruh yang lebih baik (Abdillah, 2018). Dengan demikian berdasarkan Gambar 9 dan Gambar 10 menunjukkan bahwa nilai Adjusted R Square pada kedua angket lebih kecil dari nilai $\mathrm{R}$ Square, sehingga dapat diinterpretasikan bahwa penambahan variabel independen tidak memberikan pengaruh yang makin membaik.

Apabila merujuk pada Gambar 9 dengan besaran R-Square 0,816 menunjukkan bahwa proporsi pengaruh variabel prediktor terhadap variabel pemahaman sebesar 81,6\%. Artinya, Collaborative Learning dan Implementasi LMS Moodle diperkirakan akan memiliki proporsi pengaruh terhadap pemahaman sebesar 81,6\%. Namun temuan yang didapat dari angket posttest pada Gambar 10 mengindikasikan bahwa kenyataan di lapangan tidak sesuai dengan hasil estimasi disebabkan skor Adjusted R Square yang lebih kecil dari pada nilai $\mathrm{R}$ Square, dimana setelah implementasi LMS dan model kolaboratif ditemukan bahwa kedua variabel ini hanya mempengaruhi pemahaman sebesar $49,9 \%$.

Dengan demikian dapat diinterpretasikan bahwa variabel implementasi LMS Moodle (X1) dan pendekatan pembelajaran kolaboratif (X2) tidak mempengaruhi peningkatan pemahaman belajar mahasiswa (Y) pada Prodi PTI. Hal tersebut ditunjukkan oleh nilai output pada model summary ${ }^{\mathrm{b}}$ dimana nilai kedua koefisien R Square dan Adjusted $\mathrm{R}$ Square pada angket posttest lebih kecil nilainya dibandingkan dengan angket pretest.

\section{KESIMPULAN}

Walaupun hasil estimasi sebelum dilakukan inervensi (pretest) dengan menambahkan LMS dan model pembelajaran kolaboratif memperkirakan pengaruh keduanya terhadap pemahaman mahasiswa sebesar 81,6\%, namun hasil setelah perlakuan (posttest) menunjukan persentase pemahaman hanya sebesar 49,9\%. Dengan demikian dapat disimpulkan bahwa implementasi LMS Moodle dan pendekatan model pembelajaran kolaboratif tidak mempengaruhi peningkatan pemahaman mahasiswa meskipun hasil estimasi berdasarkan data pada saat pretest dan posttest yang dimodelkan oleh metode regresi linier berganda menunjukkan arah pengaruh bernilai positif.

Temuan tersebut juga mengindikasikan bahwa hipotesis yang diajukan ditolak dikarenakan implementasi LMS pada kelas blended learning (X1) melalui pendekatan model pembelajaran kolaboratif (X2) tidak berpengaruh terhadap peningkatan pemahaman belajar mahasiswa (Y). Untuk itu diperlukan kajian lebih lanjut dari hasil penelitian ini dengan melibatkan kelompok kontrol yang sama sekali tidak menggunakan model pembelajaran kolaboratif dengan LMS Moodle. Hal ini untuk membuktikan dan menemukan faktor pendukung lainnya yang mempengaruhi temuan penelitian ini, dimana persentase hasil pretest lebih tinggi dari posttest. Selain itu disarankan pula agar simulasi dilakukan dengan membandingkan model pembelajaran kolaboratif menggunakan perangkat lunak lain yang setingkat dengan Moodle serta dapat diujikan pada matakuliah yang lebih bervariasi.

\section{DAFTAR PUSTAKA}

ABDILLAH, W., 2018. Metode Penelitian Terpadu Sistem Informasi, Yogyakarta: Penerbit Andi.

ARIFIN, F. \& HERMAN, T., 2018. Pengaruh Pembelajaran E-Learning Model Web Centric Course Terhadap Pemahaman Konsep Dan 
Kemandirian Belajar Matematika Siswa. Jurnal Pendidikan Matematika, 12(2), pp.1-12.

BOELENS, R., VOET, M. \& WEVER, B. D, 2018. The design of blended learning in response to student diversity in higher education: Instructors ' views and use of di ff erentiated instruction in blended learning. Computers \& Education, 120, pp.197-212. Tersedia melalui: https://doi.org/10.1016/j.compedu.2018.02.00 9.

BONK, C.J. dkk., 2007. The Present and Future State of Blended Learning in Workplace Learning Settings in the United States.

BOWERS, J., JUSTICE, C. \& VALLEY, S., 2015. Students, Perceptions of Teaching and Social Presence : A Comparative Analysis of Face-toFace. , 10(March), pp.27-44.

CHEUNG, R. \& VOGEL, D., 2013. Predicting user acceptance of collaborative technologies: An extension of the technology acceptance model for e-learning. Computers \& Education, 63, pp.160-175.

COMERCHERO, M., 2006. What is E-Learning? In E-Learning Concepts and Techniques. Pennsylvania: Institute for Interactive Technologies.

DEEJRING, K., 2014. The design of web-based learning model using collaborative learning techniques and a scaffolding system to enhance learners ' competency in higher education. In Procedia - Social and Behavioral Sciences. pp. 436-441.

DILLENBOURG, P. \& FISCHER, F., 2007. Computer-Supported Collaborative Learning: The Basics. Zeitschrift für Berufs- und Wirtschaftspädagogik, 21(July 2010), pp.111130.

GHOZALI, I., 2016. Aplikasi Analisis Multivariete Dengan Program IBM SPSS 23 8th ed., Semarang: Badan Penerbit Universitas Diponegoro.

GRAHAM, C.R., 2004. Blended Learning Systems: Definition, Current Trends, And Future Directions. In Handbook of blended learning: Global Perspectives, local designs. Pfeiffer Publishing.

GRAHAM, C.R., 2006. Introduction to blended learning. In The handbook of blended learning: global perspectives, local designs. pp. 1-21.

GRAHAM, C.R. \& DZIUBAN, C., 2006. Blended Learning Environments. In The handbook of blended learning: global perspectives, local designs. San Fransisco, CA: Pfeiffer Publishing, pp. 269-276.

HERLAMBANG, A.D. \& HIDAYAT, W.N., 2016. Edmodo Untuk Meningkatkan Kualitas Perencanaan Proyek Dan Efektivitas Pembelajaran Di Lingkungan Pembelajaran Yang Bersifat Asinkron. Jurnal Teknologi Informasi dan Ilmu Komputer, 3(3), pp.180-
187.

KARWATI, E., 2014. Pengaruh Pembelajaran Elektronik (E-Learning) Terhadap Mutu Belajar Mahasiswa. Jurnal Penelitian Komunikasi, 17(1), pp.41-54.

KOVACOVA, L. \& VACKOVA, M., 2015. Implementation of e-learning into the process security education in universities. In Procedia Social and Behavioral Sciences. Elsevier B.V., pp. 414-419. Tersedia melalui: http://dx.doi.org/10.1016/j.sbspro.2015.04.810

MARSDEN, E. \& TORGERSON, C.J., 2012. Single group, pre- and post-test research designs : Some methodological concerns. Oxford Review of Education, 38(5), pp.583-616. Tersedia melalui: http://dx.doi.org/10.1080/03054985.2012.7312 08.

MAS'UD, H. \& SURJONO, H.D., 2018. The Implementation of Flipped Classroom Learning Model Using Moodle To Increase Students , Higher Order Thinking Skills. Journal of Education Science and Technology, 4(3), pp.187-194.

MEDINA, L.C., 2018. Blended learning: Deficits and prospects in higher education. Australian Journal of Educational Technology, 34(1), pp.42-56.

MIRABOLGHASEMI, M., A.IAHAD, N. \& QOMARUDDIN, M., 2014. Evaluating Students' Learning Experiences Using Course Management System in a Blended Learning.

NAZIR, M., 2017. Metode Penelitian 11th ed., Bogor: Ghalia Indonesia.

OSGUTHORPE, R.T. \& GRAHAM, C.R., 2003. Blended learning systems: Definitions and directions. Quarterly Review of Distance Education, 4(3), pp.227-234.

PENG, J., JIANG, D. \& ZHANG, X., 2013. Design and implement a knowledge management system to support web-based learning in higher education. In Procedia Computer Science. Elsevier B.V., pp. 95-103. Tersedia melalui: 10.1016/j.procs.2013.09.085

Peraturan Menteri Pendidikan Dan Kebudayaan nomor 49 tahun 2014 tentang Standar Nasional Pendidikan Tinggi. Jakarta: Kementerian Pendidikan dan Kebudayaan Republik Indonesia.

PRADANA, F., RACHMADI, A. \& BACHTIAR, F.A., 2015. Penilaian Faktor Penerimaan Teknologi Blended learning di PTIIK Universitas Brawijaya dengan Metode Unified Theory of Acceptance and Use of Technology ( UTAUT ). Jurnal Teknologi Informasi dan Ilmu Komputer, 2(1), pp.49-58.

PRASETYA, S.P., 2013. Pengaruh E-Learning Dan Motivasi Belajar Terhadap Hasil Belajar Mahasiswa. Jurnal Geografi, 11(21), pp.74-82. 
PROJECT, M.G., 2013. Quality in Blended Learning, RAMIREZ, G.M., COLLAZOS, C.A. \& MOREIRA, F., 2018. All-Learning: The state of the art of the models and the methodologies educational with ICT. Telematics and Informatics, 35, pp. $944-953$.

ROBERTS, T.S., 2005. Computer-Supported Collaborative Learning in Higher Education: An Introduction. In Computer-Supported Collaborative Learning in Higher Education. Queensland: Idea Group Publishing, pp. 1-18.

ROBSON, L.S. dkk, 2001. Before-and-after design: A simple evaluation design. In Guide to evaluating the effectiveness of Strategies for Preventing Work Injuries. Cincinnati: DHHS (NIOSH), pp. 17-28.

SONGKRAM, N. dkk, 2015. E-learning system to enhance cognitive skills for learners in higher education. In Procedia - Social and Behavioral Sciences. Elsevier B.V., pp. 667-673. Tersedia melalui:http://dx.doi.org/10.1016/j.sbspro.201 5.01.599.

SPURLOCK, D.R., 2018. The Single-Group, Preand Posttest Design in Nursing Education Research: It's Time to Move on. Journal of Nursing Education, 57(2), pp.69-71.

SUBRAMANIAN, D.V. dkk, 2015. An Effective Assessment of Knowledge Sharing and ELearning Portals., 10(June), pp.1-12.

SUGIYONO, 2015. Metode Penelitian Kuantitatif, Kualitatif dan R \& D 22nd ed., Bandung: Alfabeta. 
Halaman ini sengaja dikosongkan 